Article

\title{
Tuning the oxygen evolution electrocatalysis on NiFe-layered double hydroxides via sulfur doping
}

\author{
Shenzhou Li, Jianyun Liu, Shuo Duan, Tanyuan Wang *, Qing Li \# \\ State Key Laboratory of Material Processing and Die \& Mould Technology, School of Materials Science and Engineering, Huazhong University of Science \\ and Technology, Wuhan 430074, Hubei, China
}

\section{A R T I C L E I N F}

Article history:

Received 14 October 2019

Accepted 18 November 2019

Published 5 May 2020

\section{Keywords:}

Oxygen evolution

Electrocatalysis

Layered double hydroxides

Sulfur doping

Water splitting

\begin{abstract}
A B S T R A C T
We report a facile way to prepare sulfur (S) doped $\mathrm{Ni}_{4 / 5} \mathrm{Fe}_{1 / 5}$-layered double hydroxide (LDH) electrocatalysts for oxygen evolution reaction (OER). The influence of $\mathrm{S}$ doping amount on the OER activity of the resulted NiFe-LDHs was studied and the optimal surface S content was ca. 0.43 at\%. The developed S-doped NiFe-LDH exhibits excellent OER catalyst activity in $1.0 \mathrm{M}$ KOH with overpotential of only $257 \mathrm{mV}$ at the current density of $10 \mathrm{~mA} \mathrm{~cm}^{-2}$. Moreover, the catalyst could maintain high activity after $30 \mathrm{~h}$ stability test. The high activity of the S-doped NiFe-LDH catalysts may originate from the synergistic effect between $S$ and the Fe sites. This work provides a simple but efficient way to improve the OER performance of transition metal oxides/(oxy)hydroxides.
\end{abstract}

(C) 2020, Dalian Institute of Chemical Physics, Chinese Academy of Sciences. Published by Elsevier B.V. All rights reserved.

\section{Introduction}

With the world's energy crisis and environmental pollutions, it is urgent to develop renewable energy conversion and storage technologies, such as water splitting [1-3], fuel cells $[4,5]$, lithium-ion batteries [6,7], rechargeable metal-air batteries [8-10], and $\mathrm{CO}_{2}$ conversion and utilization $[11,12]$. Oxygen evolution reaction (OER) is the unavoidable half-reaction in water splitting, electrochemical $\mathrm{CO}_{2}$ reduction, and rechargeable metal-air batteries, whereas the sluggish kinetics of OER and the high cost of the current commercial catalysts $_{\mathrm{rO}} \mathrm{O}_{2}$ and $\mathrm{RuO}_{2}$ ) severely limit the commercialization of these technologies $[13,14]$. Hence, it is necessary to develop OER electrocatalysts derived from based on earth-abundant elements with high efficiency and low-cost.

Current research on non-precious metal OER catalysts focuses on the first-row transition metal compounds [15-19].
Generally, transition metal oxides/(oxy)hydroxides show higher activity than their sulfides [16,20,21], selenides [22,23], and phosphides [24-26]. Moreover, recent studies have shown that metal sulfides, selenides, and phosphides can be converted into oxides/(oxy)hydroxides (which act as the active species for OER) in the process of OER electrocatalysis [9,21,27]. Therefore, the structure engineering of transition metal oxides/(oxy)hydroxides tends to be an attractive way for the design of high performance OER electrocatalysts [17,19, 28-31]. Transition metal-based layered double hydroxides (LDHs) are a group of excellent OER electrocatalysts due to their high specific surface areas, abundant active sites as well as the synergistic catalytic effect of bimetallic species [18,32,33]. Among the various LDHs, NiFe-LDHs have demonstrated outstanding OER activity attributable to their highly active Fe sites with modulated $3 d$ electronic structure [15,34,35]. The possible partial-charge transfer activation effect between Fe and Ni and the

\footnotetext{
* Corresponding author. Tel: +86-27-87547904; Fax: +86-27-87546587; E-mail: wangty@hust.edu.cn

\# Corresponding author. Tel: +86-27-87547904; Fax: +86-27-87546587; E-mail: qing_li@hust.edu.cn

This work was supported by the National Natural Science Foundation of China $(21603078,21705052,51602223)$.

DOI: S1872-2067(19)63356-5 | http://www.sciencedirect.com/science/journal/18722067 | Chin. J. Catal., Vol. 41, No. 5, May 2020
} 
lattice distortion of Fe site during OER are suggested to reduce the energy barriers for the formation of the OER intermediates, thus result in reduced OER overpotential $[15,36]$. To further improve the OER performance of NiFe-LDHs, defects and other metal atoms have been introduced $[37,38]$. However, the incorporation of new non-metallic atoms is rarely investigated in the OER electrocatalysis of NiFe-LDHs. Our recent work shows that the surface $\mathrm{S}$ residues in $\mathrm{NiFe}$ (oxy)hydroxide derived from $\mathrm{NiFe}$ disulfides could adjust the adsorption energy of $\mathrm{OH}^{*}$ and $0^{*}$ on the Fe sites, leading to enhanced OER activity [34]. In this work, we synthesize and systematically study the OER activity of S doped NiFe-LDHs and demonstrate that the proper introduction of S can significantly improve the OER performance of NiFe-LDHs.

\section{Experimental}

\subsection{Synthesis of $\mathrm{Ni}_{4 / 5} \mathrm{Fe}_{1 / 5}-\mathrm{LDHs}$}

The $\mathrm{Ni}_{4 / 5} \mathrm{Fe}_{1 / 5}$-LDHs catalyst was fabricated by the hydrothermal method [18]. Briefly, $0.18 \mathrm{mmol}$ nickel acetate tetrahydrate (99.9\%, Aladdin) and $0.03 \mathrm{mmol}$ iron nitrate nonahydrate (AR, Aladdin) were dissolved in $16 \mathrm{ml}$ deionized water and $8 \mathrm{ml}$ DMF (99.5\%, Aladdin). The mixture was transferred into a Teflon container and heated at $120{ }^{\circ} \mathrm{C}$ for $12 \mathrm{~h}$. After cooling down to room temperature naturally, the obtained mixed solution containing light yellow precipitation is centrifuged at $9000 \mathrm{rpm}$ and washed with deionized water and ethanol. The precipitate is then freeze-dried by a lyophilizer, follow by grinding to obtain the final product.

\subsection{Synthesis of S-doped $\mathrm{Ni}_{4 / 5} \mathrm{Fe}_{1 / 5}-\mathrm{LDHs}$}

To synthesize S-doped $\mathrm{Ni}_{4 / 5} \mathrm{Fe}_{1 / 5}$-LDHs, a certain amount of thiourea (99\%, Aladdin) was added into the mixture as the S source and other procedures were kept the same. To study the effect of S content, $0.005,0.01,0.02,0.04$ and $0.08 \mathrm{mmol}$ thiourea were added, and the resulting products were named $\mathrm{Ni}_{4 / 5} \mathrm{Fe}_{1 / 5}$-LDHs-S-1, Ni $4 / 5 \mathrm{Fe}_{1 / 5}$-LDHs-S-2, Ni4/5Fe $1 / 5$-LDHs-S-3, $\mathrm{Ni}_{4 / 5} \mathrm{Fe}_{1 / 5}$-LDHs-S-4 and $\mathrm{Ni}_{4 / 5} \mathrm{Fe}_{1 / 5}$-LDHs-S-5, respectively.

\subsection{Characterization}

The X-ray diffraction (XRD, Rigaku, DMAX-2400) was used to analyze the crystal structure of the catalysts, and the $2 \theta$ range from $10^{\circ}$ to $80^{\circ}$. Scanning electron microscope (SEM, FEI, Sirion 200) images and transmission electron microscopy (TEM, FEI, Tecnai G2 20) images were collected to observe the morphology directly. X-ray photoelectron spectroscopy (XPS, Shimadzu, AXIS-ULTRA DLD-600W) was acquired to understand the catalyst's surface composition and the surface energy state distribution, and the C $1 s$ hydrocarbon peek at $284.6 \mathrm{eV}$ was used to revise the binding energy. X-ray fluorescence (XRF, EDAX, EAGLE III) was carried out to detect the type and content of various elements in the sample.

\subsection{Electrochemical measurement}

The catalyst ink for electrochemical testing were prepared by mixing the catalyst and $\mathrm{KJ}$ black carbon with the mass ratio of 4:1 in $800 \mu \mathrm{l}$ isopropanol and $200 \mu \mathrm{l}$ deionized water, then ultrasonication for one hour. The working electrode was prepared by dropping the ink on glass carbon with the catalyst loading of $0.2 \mathrm{mg} \mathrm{cm}^{-2}$. The carbon rod and the saturated calomel electrode were used as the counter and the reference electrodes, respectively. All the potentials were converted to RHE (Platinized platinum wire inserted into the electrolyte continuously bubbling with pure hydrogen) scale experimentally. All the electrochemical OER testing was carried out in $1.0 \mathrm{M} \mathrm{KOH}$ at room temperature on $\mathrm{CHI} 760 \mathrm{D}$ (Chenhua, China). The stability test was carried out at the current density of $10 \mathrm{~mA} \mathrm{~cm}^{-2}$ by chronopotentiometry. Electrochemical impedance spectroscopy (EIS) was also collected under the appropriate voltage.

\section{Results and discussion}

The one-step hydrothermal syntheses of the $\mathrm{Ni}_{4 / 5} \mathrm{Fe}_{1 / 5}$-LDHs-S catalysts are illustrated in Fig. 1(a). The lamellar morphology of the $\mathrm{Ni}_{4 / 5} \mathrm{Fe}_{1 / 5}$-LDHs-S- 2 catalysts can be clearly observed by the SEM (Fig. 1(b)) and TEM (Fig. 1(c)) images of the $\mathrm{Ni}_{4 / 5} \mathrm{Fe}_{1 / 5}$-LDHs-S-2 sample with thickness of tens of nanometers. Meanwhile, other $\mathrm{Ni}_{4 / 5} \mathrm{Fe}_{1 / 5}-\mathrm{LDHs}$ and $\mathrm{Ni}_{4} / 5 \mathrm{Fe}_{1 / 5}$-LDHs-S catalysts (Figs. S1 and S2) also reveal similar nanosheet structures, suggesting that the $\mathrm{S}$ doping amount plays an insignificant role in determining the catalyst morphology.

The XRD patterns of $\mathrm{Ni}_{4} / 5 \mathrm{Fe}_{1 / 5}-\mathrm{LDHs}$ and $\mathrm{Ni}_{4 / 5} \mathrm{Fe}_{1 / 5}$-LDHs-S-2 are shown in Fig. 1(d), and both of their patterns are consistent with the jamborite UCPDF No. 89-1495), which is a hybrid of $\beta$-nickel hydroxide and $\gamma$-nickel (oxy)hydroxide and is hydrotalcite-like compound (HTLC, belong to LDH). Compared to the standard PDF card, the diffraction peaks of $\mathrm{Ni}_{4 / 5} \mathrm{Fe}_{1 / 5}$-LDHs and $\mathrm{Ni}_{4 / 5} \mathrm{Fe}_{1 / 5}$-LDHs-S-2 shift negatively, likely due to the increased lattice parameter by replacement of nickel with iron (oxy)hydroxide and [20]. Similarly, the XRD patterns of $\mathrm{Ni}_{4 / 5} \mathrm{Fe}_{1 / 5}$-LDHs-S-1, $\mathrm{Ni}_{4 / 5} \mathrm{Fe}_{1 / 5}$-LDHs-S-3, $\quad \mathrm{Ni}_{4 / 5} \mathrm{Fe}_{1 / 5}$-LDHs-S-4, and $\mathrm{Ni}_{4 / 5} \mathrm{Fe}_{1 / 5}$-LDHs-S-5 (Fig. S3) can be well indexed to that of the jamborite, indicating that the trace $\mathrm{S}$ doping would not affect the crystal structure of $\mathrm{Ni}_{4 / 5} \mathrm{Fe}_{1 / 5}$-LDHs. Meanwhile, the XRF measurements manifest that the $\mathrm{Ni} / \mathrm{Fe}$ ratios of all samples are close to $4: 1$.

The elemental composition and bonding configuration of the obtained samples are detected by XPS. All the binding energies are calibrated by the reference of the $\mathrm{C} 1 \mathrm{~s}$ peak, whose position is at $284.6 \mathrm{eV}$. The peak of $\mathrm{Ni} 2 p_{3 / 2}$ of $\mathrm{Ni}_{4 / 5} \mathrm{Fe}_{1 / 5}$ - LDHs (Fig. 2(a)) is located at $855.4 \mathrm{eV}$, which is regarded as the Ni (II) that is bonded with $\mathrm{OH}$. The $\mathrm{Ni} 2 p_{3 / 2}$ peak of $\mathrm{Ni}_{4 / 5} \mathrm{Fe}_{1 / 5}$-LDHs-S-2 (Fig. 2(b)) is at $855.5 \mathrm{eV}$, indicating that the binding energy of $\mathrm{Ni}$ is not significantly altered by $\mathrm{S}$ doping. In the contrast, the peaks of $\mathrm{Fe} 2 p_{3 / 2}$ for $\mathrm{Ni}_{4 / 5} \mathrm{Fe}_{1 / 5}$-LDHs (Fig. 2(c)) and $\mathrm{Ni}_{4 / 5} \mathrm{Fe}_{1 / 5}$-LDHs-S-2 (Fig. 2(d)) are at 712.96 and $712.44 \mathrm{eV}$, respectively, which can be assigned to Fe(III). The decrease of binding energy suggests that the electron density 

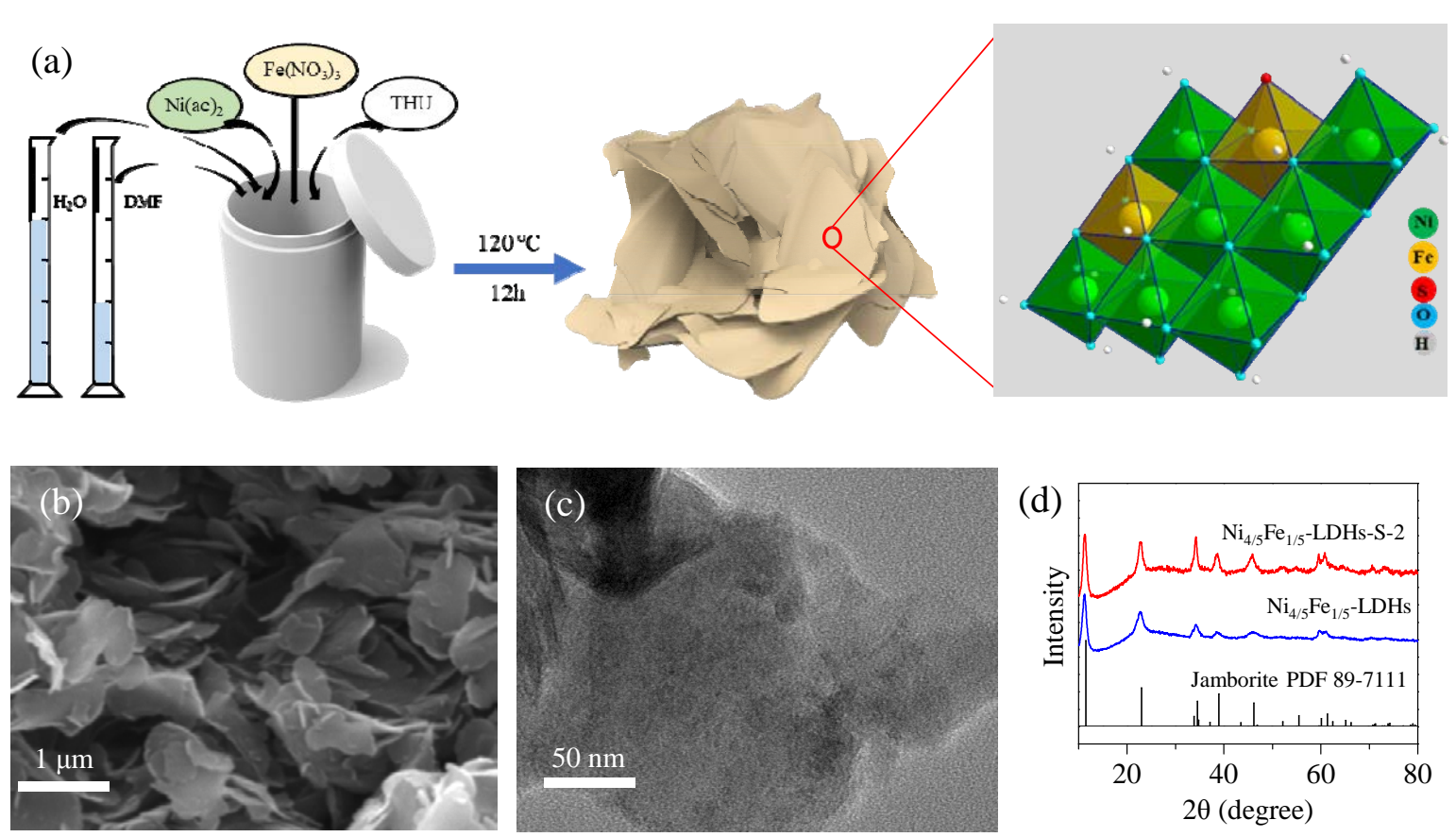

Fig. 1. (a) Schematic illustration of the synthetic procedure of the $\mathrm{Ni}_{4 / 5} \mathrm{Fe}_{1 / 5}-\mathrm{LDHs}-\mathrm{S}-2$ sample; SEM (b) and TEM (c) images of the $\mathrm{Ni}_{4 / 5} \mathrm{Fe}_{1 / 5}-\mathrm{LDHs}$-S-2 sample; (d) XRD patterns of the $\mathrm{Ni}_{4 / 5} \mathrm{Fe}_{1 / 5}$-LDHs-S-2 and $\mathrm{Ni}_{4 / 5} \mathrm{Fe}_{1 / 5}$-LDHs samples.
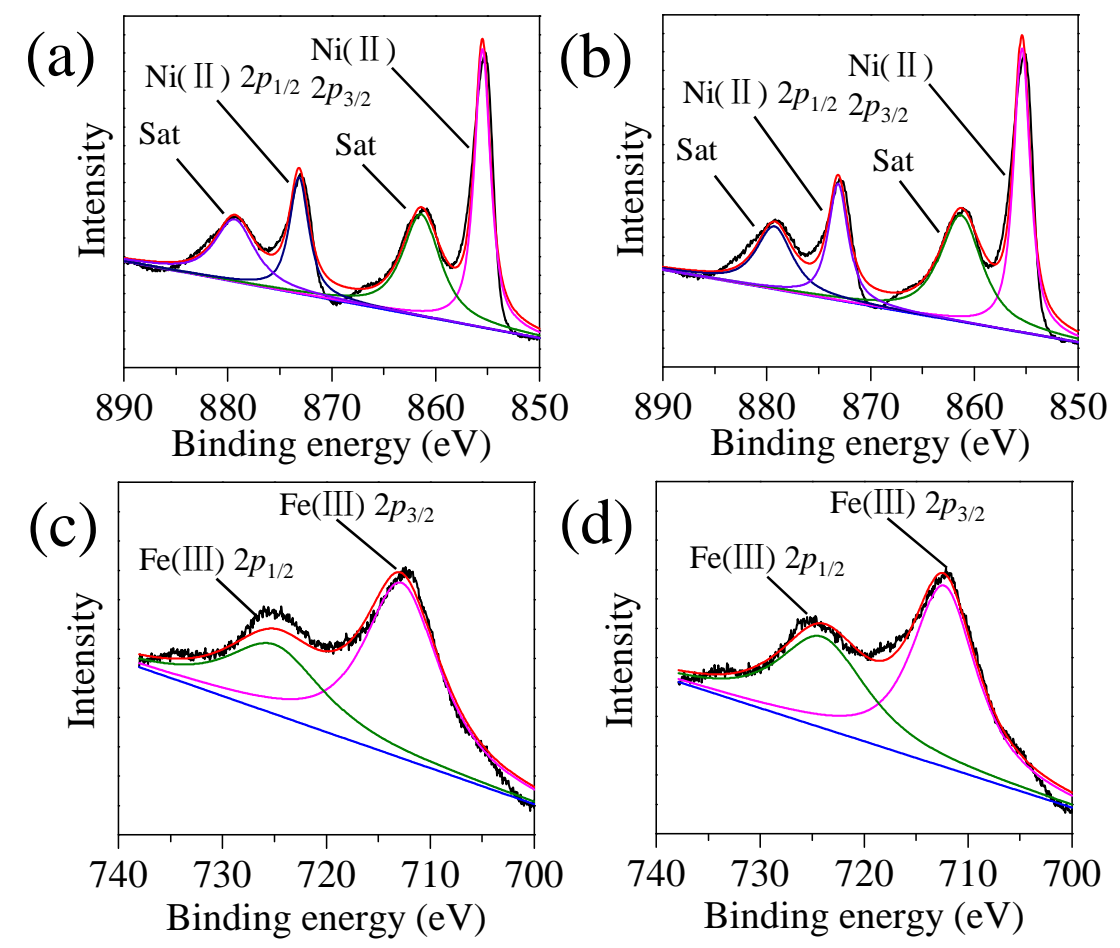

Fig. 2. High resolution Ni $2 p$ and Fe $2 p$ XPS spectra for $\mathrm{Ni}_{4 / 5} \mathrm{Fe}_{1 / 5} \mathrm{OH}-\mathrm{LDHs}$ (a, c), and $\mathrm{Ni}_{4 / 5} \mathrm{Fe}_{1 / 5} \mathrm{OH}-\mathrm{LDHs}-\mathrm{S}-2$ (b, d).

on the surface of Fe atoms gets denser after S doping, attesting to the strong interaction between $\mathrm{Fe}$ and $\mathrm{S}$. The $\mathrm{S}$ has lower electronegativity compared to 0 , which would decrease the valence state of Fe when $\mathrm{O}$ is partially replaced by $\mathrm{S}$. It is also observed that the peak of $\mathrm{S} 2 p_{3 / 2}$ (Fig. S4) is at $167.39 \mathrm{eV}$, suggesting the interaction of $\mathrm{S}$ with $\mathrm{O}$ rather than only sulfide. Elemental analysis by XPS shows that the surface $S$ contents of
$\mathrm{Ni}_{4 / 5} \mathrm{Fe}_{1 / 5}$-LDHs-S-2, Ni $4 / 5 \mathrm{Fe}_{1 / 5}$-LDHs-S-3, Ni $\mathrm{N}_{4} / 5 \mathrm{Fe}_{1 / 5}$-LDHs-S-4, and $\mathrm{Ni}_{4 / 5} \mathrm{Fe}_{1 / 5}$-LDHs-S-5 is $0.43 \%, 1.37 \%, 2.30 \%$, and $3.56 \%$, respectively. S contents measured by XRF ( 1 at $\%-4$ at $\%)$ is also comparable with that from XPS.

Since the poor electron-conductivity of jamborite severely limits the OER performance of the catalysts, KJ black carbon is used as the conductive supports to mix with the catalysts. The 

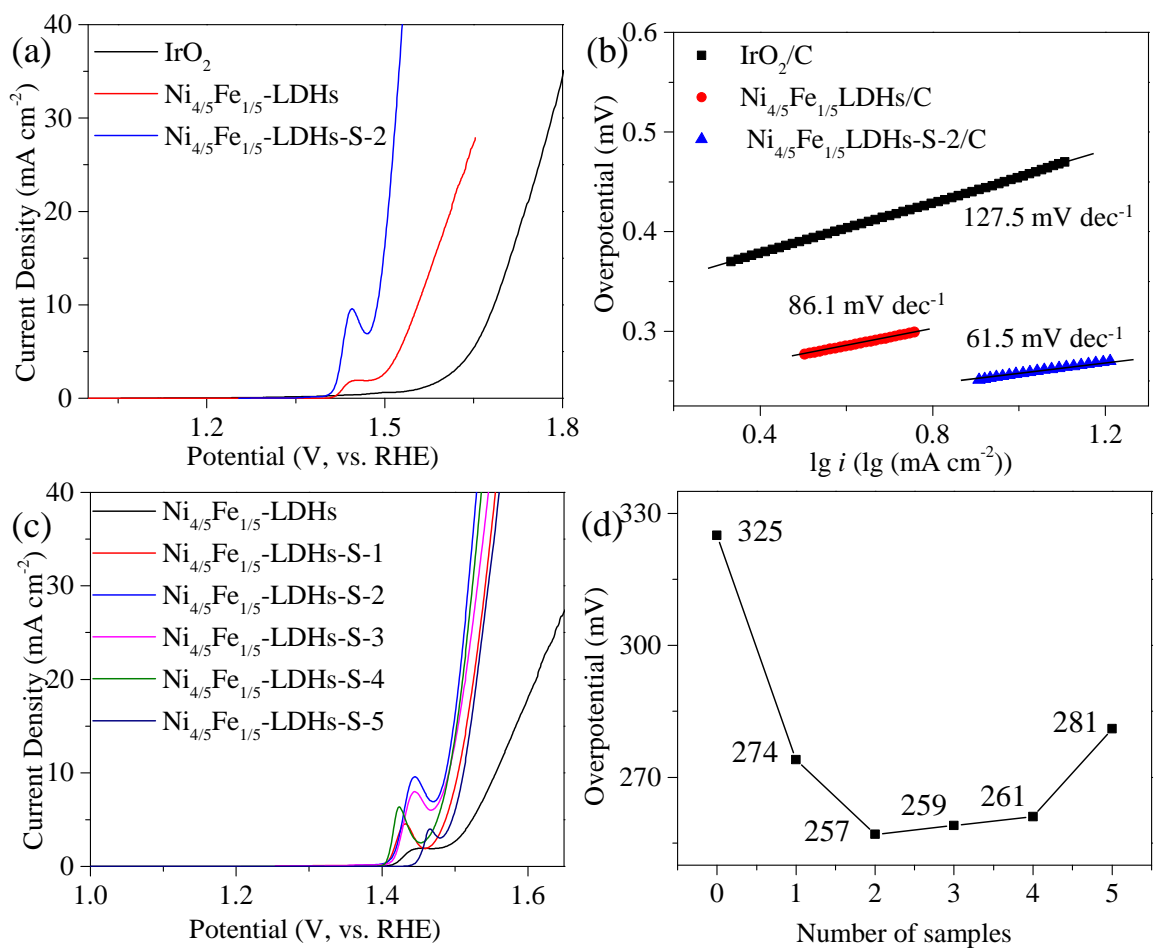

Fig. 3. (a) LSV curves of $\mathrm{IrO}_{2}, \mathrm{Ni}_{4 / 5} \mathrm{Fe}_{1 / 5}-\mathrm{LDHs}$ and $\mathrm{Ni}_{4 / 5} \mathrm{Fe}_{1 / 5}-\mathrm{LDHs}-\mathrm{S}-2$ in $1.0 \mathrm{M} \mathrm{KOH}$ at a scan rate of $10 \mathrm{mV} \mathrm{s}^{-1}$. (b) Tafel of IrO $\mathrm{T}_{2}$, $\mathrm{Ni}_{4 / 5} \mathrm{Fe}_{1 / 5}-\mathrm{LDHs}_{\mathrm{H}}$ and $\mathrm{Ni}_{4 / 5} \mathrm{Fe}_{1 / 5}$-LDHs-S-2 toward OER. (c) LSV curves of the $\mathrm{Ni}_{4 / 5} \mathrm{Fe}_{1 / 5}$-LDHs with the difference adulteration amounts. And the point plot of the OER overpotential of catalyst are showed on (d).

OER activity of the developed catalysts are evaluated by linear sweep voltammetry (LSV) in 1.0 M KOH. Fig. 3(a) demonstrates that the overpotential of $\mathrm{Ni}_{4 / 5} \mathrm{Fe}_{1 / 5}$-LDHs-S-2, $\mathrm{Ni}_{4 / 5} \mathrm{Fe}_{1 / 5}$-LDHs, and $\mathrm{IrO}_{2}$ at $10 \mathrm{~mA} \mathrm{~cm}^{-2}$ is 257,325 , and $450 \mathrm{mV}$, respectively. Similar with most literatures, $\mathrm{Ni}_{4 / 5} \mathrm{Fe}_{1 / 5}$-LDHs without $\mathrm{S}$ doping outperform $\mathrm{IrO}_{2}$ in OER electrocatalysis. On the other hand, the S-doped $\mathrm{Ni}_{4 / 5} \mathrm{Fe}_{1 / 5}$-LDHs presents excellent OER activity with an overpotential of only $257 \mathrm{mV}$ at $10 \mathrm{mAcm}^{-2}$, which is superior to most of the reported OER electrocatalysts [39-41]. Importantly, the introduction of trace $S$ significantly reduces the overpotential of $\mathrm{Ni}_{4 / 5} \mathrm{Fe}_{1 / 5}-\mathrm{LDHs}$ by $68 \mathrm{mV}$ at $10 \mathrm{~mA} \mathrm{~cm}^{-2}$. The lowered $\mathrm{Fe}$ valence state in the $\mathrm{Ni}_{4 / 5} \mathrm{Fe}_{1 / 5}$-LDHs-S- 2 catalyst, as evidenced in XPS, may relieve the energy barriers for the formation of the OER intermediates $\left(\mathrm{OH}^{*}\right.$ to $\left.\mathrm{O}^{*}\right)$ on $\mathrm{Fe}$ sites of $\mathrm{Ni}_{4 / 5} \mathrm{Fe}_{1 / 5}$-LDHs, which potentially favors the OER electrocatalysis [19]. The Tafel slope of $\mathrm{Ni}_{4 / 5} \mathrm{Fe}_{1 / 5}$-LDHs-S-2 is only $61.5 \mathrm{mV}$ $\mathrm{dec}^{-1}$, far lower than the $86.1 \mathrm{mV} \mathrm{dec}^{-1}$ of $\mathrm{Ni}_{4 / 5} \mathrm{Fe}_{1 / 5}$-LDHs and $127.5 \mathrm{mV} \mathrm{dec}^{-1}$ of $\mathrm{IrO}_{2}$. EIS (Fig. S7) is also measured to understand the effect of $S$ doping. The charge transfer resistance of $\mathrm{Ni}_{4 / 5} \mathrm{Fe}_{1 / 5}$-LDHs-S-2 is $80 \Omega$ at the overpotential of $260 \mathrm{mV}$, which is only half of the resistance of $\mathrm{Ni}_{4 / 5} \mathrm{Fe}_{1 / 5}$-LDHs at the same overpotential. The lower charge transfer resistance suggests the smaller reaction barrier on $\mathrm{Ni}_{4 / 5} \mathrm{Fe}_{1 / 5}$-LDHs-S- 2 , which also contributes to the OER electrocatalysis enhancement.

The influence of $S$ doping amount on OER activity of $\mathrm{Ni}_{4 / 5} \mathrm{Fe}_{1 / 5}$-LDHs-S catalysts is also explored (Figs. 3(c) and 3(d)). Initially, with the increase of $\mathrm{S}$ content to 0.43 at $\%$
( $\mathrm{Ni}_{4} / 5 \mathrm{Fe}_{1 / 5}$-LDHs-S-2), the overpotential of $\mathrm{Ni}_{4 / 5} \mathrm{Fe}_{1 / 5}$-LDHs-S for OER significantly decreases. Further increasing $\mathrm{S}$ content to 3.56 at $\%$ leads to the reduced OER activity of the $\mathrm{Ni}_{4 / 5} \mathrm{Fe}_{1 / 5}$-LDHs-S catalysts, but still better than undoped $\mathrm{Ni}_{4 / 5} \mathrm{Fe}_{1 / 5}$-LDHs.

Stability under working conditions is another important requirement for electrocatalysts. To evaluate the stability of the $\mathrm{Ni}_{4 / 5} \mathrm{Fe}_{1 / 5}$-LDHs-S-2 catalyst, it is coated on hydrophilic carbon paper and tested at the constant $10 \mathrm{~mA} \mathrm{~cm}^{-2}$ for more than 30 h. Fig. 4 illustrates that that the OER overpotential change is less than $14 \mathrm{mV}$ after $30 \mathrm{~h}$ continuous testing, demonstrating the outstanding durability of the developed $\mathrm{Ni}_{4 / 5} \mathrm{Fe}_{1 / 5}$-LDHs-S-2 catalyst. SEM image (Fig. S8) of the catalyst after OER show that $\mathrm{Ni}_{4 / 5} \mathrm{Fe}_{1 / 5}$-LDHs-S-2 sheets tend to stack together after OER test. The XRD pattern of the $\mathrm{Ni}_{4 / 5} \mathrm{Fe}_{1 / 5}$-LDHs-S-2 catalyst after OER test is demonstrated in Fig. S9. The weak diffraction peaks suggest that its structure become amorphous after OER test, which is consistent with literature reports and may be beneficial to the improvement of OER activity [42]. But the typical peaks for Ni-based (oxy)hydroxide can still be recognized from the XRD pattern. To further investigate the durability of the catalysts, potential cycling form 1.0 to $1.5 \mathrm{~V}$ vs. RHE is applied to the $\mathrm{Ni}_{4 / 5} \mathrm{Fe}_{1 / 5}$-LDHs-S-2 catalyst. After 2000 potential cycles, only slight degradation can be observed (Fig. S10), corroborating the excellent durability of the developed catalyst.

\section{Conclusions}




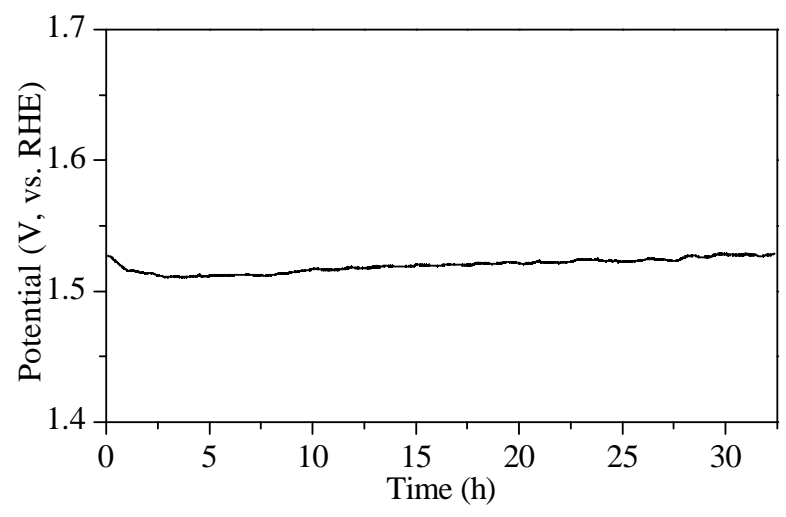

Fig. 4. Stability test of the $\mathrm{Ni}_{4 / 5} \mathrm{Fe}_{1 / 5}-\mathrm{LDHs}$ coated on carbon paper at a current density of $10 \mathrm{mAcm}^{-2}$.

In conclusion, we report a facile and efficient strategy to improve the OER activity of NiFe-LDHs by $\mathrm{S}$ doping. It is found that trace $\mathrm{S}\left(\sim 0.43\right.$ at\%) introduced in $\mathrm{Ni}_{4 / 5} \mathrm{Fe}_{1 / 5}$-LDHs plays a vital role in boosting its catalytic activity towards OER. The best performing $\mathrm{S}$ doped $\mathrm{Ni}_{4 / 5} \mathrm{Fe}_{1 / 5}$-LDHs catalyst demonstrates excellent OER performance with an overpotential of $257 \mathrm{mV}$ at $10 \mathrm{~mA} \mathrm{~cm}^{-2}$ and a Tafel slope of $61.5 \mathrm{mV} \mathrm{dec}^{-1}$ as well as outstanding stability. XPS measurements suggest that the interaction between surface $\mathrm{S}$ and Fe reduces the valence state of $\mathrm{Fe}$, which may reduce the energy barriers for the formation of the OER intermediates on Fe sites and thus enhance the OER activity according to our previous research. This work offers an easy way to engineer the structure and electronic state of transition metal oxides by non-metallic elemental doping, which would be a promising method for the design of highly active OER electrocatalysts.

\section{Acknowledgments}

The authors thank the Analytical and Testing Center of Huazhong University of Science and Technology (HUST) for carrying out the XRD and XPS measurements.

\section{References}

[1] M. G. Walter, E. L. Warren, J. R. McKone, S. W. Boettcher, Q. X. Mi, E. A. Santori, N. S. Lewis, Chem. Rev., 2010, 110, 6446-6473.

[2] S. J. A. Moniz, S. A. Shevlin, D. J. Martin, Z. X. Guo, J. W. Tang, Energy Environ. Sci., 2015, 8, 731-759.

[3] T. Wang, H. Xie, M. Chen, A. D'Aloia, J. Cho, G. Wu, Q. Li, Nano Energy, 2017, 42, 69-89.

[4] Z. Miao, X. Wang, M.-C. Tsai, Q. Jin, J. Liang, F. Ma, T. Wang, S. Zheng, B.-J. Hwang, Y. Huang, S. Guo, Q. Li, Adv. Energy Mater. 2018, 8, 1801226.

[5] Y. Ji, L. Yang, X. Ren, G. Cui, X. Xiong, X. Sun, ACS Sustain. Chem. Eng., 2018, 6, 9555-9559.

[6] J. B. Goodenough, Y. Kim, Chem. Mater., 2010, 22, 587-603.

[7] Q. Li, P. Xu, W. Gao, S. Ma, G. Zhang, R. Cao, J. Cho, H.-L. Wang, G. Wu, Adv. Mater., 2014, 26, 1378-1386.

[8] F. Cheng, J. Chen, Chem. Soc. Rev., 2012, 41, 2172-2192.

[9] Z. L. Wang, D. Xu, J. Xu, X. B. Zhang, Chem. Soc. Rev., 2014, 43,
7746-7786.

[10] Y. Li, M. Gong, Y. Liang, J. Feng, J. Kim, H. Wang, G. Hong, B. Zhang, H. Dai, Nat. Commun., 2013, 4, 1805.

[11] H. Xie, T. Wang, J. Liang, Q. Li, S. Sun, Nano Today, 2018, 21, 41-54.

[12] H. Xie, S. Chen, F. Ma, J. Liang, Z. Miao, T. Wang, H.-L. Wang, Y. Huang, Q. Li, ACS Appl. Mater. Interfaces, 2018, 10, 36996-37004.

[13] Y. Surendranath, M. W. Kanan, D. G. Nocera, J. Am. Chem. Soc., 2010, 132, 16501-16509.

[14] N.-T. Suen, S.-F. Hung, Q. Quan, N. Zhang, Y.-J. Xu, H. M. Chen, Chem. Soc. Rev., 2017, 46, 337-365.

[15] L. Trotochaud, S. L. Young, J. K. Ranney, S. W. Boettcher, J. Am. Chem. Soc., 2014, 136, 6744-6753.

[16] W. Chen, H. Wang, Y. Li, Y. Liu, J. Sun, S. Lee, J. Lee, Y. Cui, ACS Central Sci., 2015, 1, 244-251.

[17] P. Chen, K. Xu, Z. Fang, Y. Tong, J. Wu, X. Lu, X. Peng, H. Ding, C. Wu, Y. Xie, Angew. Chem. Int. Ed., 2015, 54, 14710-14714.

[18] M. Gong, Y. Li, H. Wang, Y. Liang, J. Wu, J. Zhou, J. Wang, T. Regier, F. Wei, H. Dai, J. Am. Chem. Soc., 2013, 135, 8452-8455.

[19] L. Xu, Q. Jiang, Z. Xiao, X. Li, J. Huo, S. Wang, L. Dai, Angew. Chem. Int. Ed., 2016, 55, 5277-5281.

[20] T. Wang, G. Nam, Y. Jin, X. Wang, P. Ren, M. Kim, J. Liang, X. Wen, H. Jang, J. Han, Y. Huang, Q. Li, J. Cho, Adv. Mater., 2018, 30, 1800757.

[21] X. Xu, F. Song, X. L. Hu, Nat. Commun., 2016, 7, 12324.

[22] C. Tang, N. Cheng, Z. Pu, W. Xing, X. Sun, Angew. Chem. Int. Ed., 2015, 54, 9351-9355.

[23] Y. Liu, H. Cheng, M. J. Lyu, S. Fan, Q. Liu, W. Zhang, Y. Zhi, C. Wang, C. Xiao, S. Wei, B. Ye, Y. Xie, J. Am. Chem. Soc., 2014, 136, 15670-15675.

[24] T. Wang, C. Wang, Y. Jin, A. Sviripa, J. Liang, J. Han, Y. Huang, Q. Li, G. Wu, J. Mater. Chem. A, 2017, 5, 25378-25384.

[25] L. A. Stern, L. G. Feng, F. Song, X. Hu, Energy Environ. Sci., 2015, 8, 2347-2351.

[26] X. Ji, R. Zhang, X. Shi, A. M. Asiri, B. Zheng, X. Sun, Nanoscale, 2018, $10,7941-7945$.

[27] M. Zhou, Q. Weng, X. Zhang, X. Wang, Y. Xue, X. Zeng, Y. Bando, D. Golberg, J. Mater. Chem. A, 2017, 5, 4335-4342.

[28] W. Zhou, X. J. Wu, X. Cao, X. Huang, C. Tan, J. Tian, H. Liu, J. Wang, H. Zhang, Energy Environ. Sci., 2013, 6, 2921-2924.

[29] K. Fominykh, J. M. Feckl, J. Sicklinger, M. Doblinger, S. Bocklein, J. Ziegler, L. Peter, J. Rathousky, E. W. Scheidt, T. Bein, D. Fattakhova-Rohlfing, Adv. Funct. Mater., 2014, 24, 3123-3129.

[30] S. Chen, J. J. Duan, P. J. Bian, Y. H. Tang, R. K. Zheng, S. Z. Qiao, Adv. Energy Mater., 2015, 5, 1500936.

[31] J. Zhang, D. Zhang, R. Zhang, N. Zhang, C. Cui, J. Zhang, B. Jiang, B, Yuan, T. Wang, H. Xie, Q. Li, ACS Appl. Energy Mater., 2018, 1, 495-502.

[32] M. Gong, Y. Li, H. Wang, Y. Liang, J. Z. Wu, J. Zhou, J. Wang, T. Regier, F. Wei, H. Dai, J. Am. Chem. Soc., 2013, 135, 8452-8455.

[33] Q. Wang, D. O'Hare, Chem. Rev., 2012, 112, 4124-4155.

[34] D. Friebel, M. W. Louie, M. Bajdich, K. E. Sanwald, Y. Cai, A. M. Wise, M. J. Cheng, D. Sokaras, T. C. Weng, R. Alonso-Mori, R. C. Davis, J. R. Bargar, J. K. Norskov, A. Nilsson, A. T. Bell, J. Am. Chem. Soc., 2015, 137, 1305-1313.

[35] J. Zhao, X. Li, G. Cui, X. Sun, Chem. Commun., 2018, 54, 5462-5465.

[36] M. W. Louie, A. T. Bell, J. Am. Chem. Soc., 2013, 135, 12329-12337.

[37] S. Chen, J. Duan, M. Jaroniec, S. Z. Qiao, Angew. Chem. Int. Ed., 2013, 52, 13567-13570.

[38] C. G. Morales-Guio, L. Liardet, X. Hu, J. Am. Chem. Soc., 2016, 138, 8946-8957.

[39] H. Shi, H. Liang, F. Ming, Z. Wang, Angew. Chem. Int. Ed., 2017, 56, 573-577. 


\title{
Graphical Abstract
}

Chin. J. Catal., 2020, 41: 847-852 doi: S1872-2067(19)63356-5

Tuning the oxygen evolution electrocatalysis on NiFe-layered double hydroxides via sulfur doping

Shenzhou Li, Jianyun Liu, Shuo Duan, Tanyuan Wang *, Qing Li * Huazhong University of Science and Technology

The activity of $\mathrm{Ni}_{4 / 5} \mathrm{Fe}_{1 / 5}$-LDHs for oxygen evolution reaction is significantly enhanced by the introducing of trace amount of $\mathrm{S}$. The interaction between surface $\mathrm{S}$ and $\mathrm{Fe}$ is suggested to contribute to this improved electrocatalytic performance.

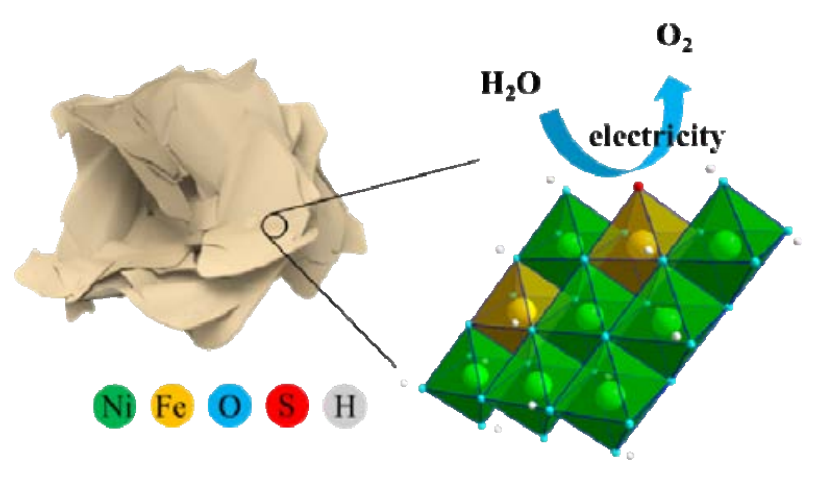

[40] C. Xiao, X. Lu, C. Zhao, Chem. Commun., 2014, 50, 10122-10125.

[41] C. Z. Zhu, D. Wen, S. Leubner, M. Oschatz, W. Liu, M. Holzschuh, F. Simon, S. Kaskel, A. Eychmuller, Chem. Commun., 2015, 51,

7851-7854.

[42] Z. Lu, W. Xu, W. Zhu, Q. Yang, X. Lei, J. Liu, Y. Li, X. Sun, X. Duan, Chem. Commun., 2014, 50, 6479-6482.

\section{硫掺杂镍铁层状双氢氧化物的氧析出电催化性能}

\author{
李申宙, 刘健云, 段 炼, 王谭源*, 李 箐\# \\ 华中科技大学材料科学与工程学院, 湖北武汉 430074
}

摘要: 氧析出反应(OER)是裂解水、二氧化碳还原、以及可充电的锌空电池等许多技术中重要的半反应,但受限于其迟缓 的反应动力学, 开发高效的氧析出催化剂迫在眉睫. 在OER出反应中, 性能较好的非贵金属催化剂主要是第四周期过渡金 属的一些化合物, 如氧化物、氢氧化物、硫化物、硒化物、磷化物等等. 在这些材料中, 镍铁双金属化合物被认为是最优的 氧析出材料, 尤其是镍铁层状双氢氧化物(NiFe-LDHs) 它拥有较大的电化学活性面积以暴露较多活性位点, 同时镍铁两种过 渡金属元素存在协同效应,使得其具有良好的催化性能. 然而, 这一类材料的OER性能仍然有优化的空间. 研究表明, 将硫化 物氧化得到的氢氧化物会有少量的硫元素残留,这种硫残留的氢氧化物拥有十分优异的OER性能. 为了进一步认识硫的引 入对NiFe-LDHs的OER行为的影响, 本文通过水热法合成了硫掺杂的NiFe-LDHs, 考察了硫的掺杂量对催化剂性能的影响, 验证了微量硫的存在对NiFe-LDHs的OER性能的贡献.

扫描电镜图片显示, 水热合成的催化剂是厚度为几十纳米的薄片, 拥有较高的比表面积, X射线苂光光谱分析证明合成 的硫掺杂NiFe-LDHs中镍铁的元素比例为 $4: 1$, 而且硫的掺杂量并不影响催化剂的形貌和其中镍铁元素比. X射线光电子能 谱分析表明, 硫原子的引入使得铁原子结合能降低, 即硫与铁的相互作用部分降低了铁的价态, 这种硫和铁的相互作用能够 优化OER反应中间体 $\mathrm{OH}^{*}$ 与 $\mathrm{O} *$ 在铁活性位点上的吸附自由能, 降低氧析出反应的过电势. 电化学测试表明, 拥有 $0.43 \%$ 的硫 掺杂NiFe-LDHs拥有最好的氧析出性能, $10 \mathrm{~mA} \mathrm{~cm}^{-1}$ 下超电势仅有 $257 \mathrm{mV}$, Tafel斜率 $61.5 \mathrm{mV} \mathrm{dec}^{-1}$. 此后, 随着硫掺杂量的提 升, 其性能先保持稳定, 随后有所下降. 在稳定测试中, 硫掺杂的镍铁层状双氢氧化物在 $10 \mathrm{~mA} \mathrm{~cm}^{-1}$ 电流密度下循环 $30 \mathrm{~h}$ 后过 电位仅衰减 $14 \mathrm{mV}$. 在对稳定性测试后的催化剂进行表征表明, 催化剂发生了轻微了变形, 但这对性能的影响不大. 综上, 本 文提供了一种简便的通过非金属元素掺杂调控过渡金属氧化物的结构和电子态的方法, 有望为设计高活性OER电催化剂 提供新思路.

关键词: 氧析出; 电催化; 层状双氢氧化物; 硫掺杂; 水裂解

收稿日期: 2019-10-14. 接受日期: 2019-11-18. 出版日期: 2020-05-05.

*通讯联系人. 电话: (027)87547904; 传真: (027)87546587; 电子信箱: wangty@hust.edu.cn

”通讯联系人. 电话: (027)87547904; 传真: (027)87546587; 电子信箱: qing_li@hust.edu.cn

基金来源：国家自然科学基金(21603078, 21705052, 51602223).

本文的电子版全文由Elsevier出版社在ScienceDirect上出版(http://www.sciencedirect.com/science/journal/18722067). 